\title{
IMPLEMENTASI SISTEM E-VOTING BERBASIS ANDROID PADA SISTEM PEMILIHAN LANGSUNG DI LINGKUNGAN UNIVERSITAS ADVENT INDONESIA MENGGUNAKAN FRAMEWORK LARAVEL
}

\author{
Yulianus Palopak \\ Fakultas Teknologi Informasi Universitas Advent Indonesia
}

\begin{abstract}
Abstrak
Tujuan yang ingin dicapai dalam penelitian ini adalah menyediakan sebuah sistem yang dapat digunakan oleh para pemilih dalam memilih kandidat yang diinginkan melalui media smartphone berabasis android. Implementasi sistem e-voting pada pemilihan mahasiswa berprestasi di Universitas Advent Indonesia (UNAI) menunjukkan bahwa minat penggunaan sistem e-voting sangat tinggi dan ternyata sangat membantu dalam proses pemilihan tersebut. Lebih dari $84 \%$ pemilih yang menggunakan sistem e-voting pada kegiatan pemilihan mahasiswa berprestasi UNAI memberikan respon dan rating yang sangat baik terhadap penggunaan aplikasi. Dari sejumlah pengguna, sebanyak 81 pemilih yang memberikan ulasan singkat mengenai aplikasi dan penggunaannya, $68,4 \%$ diantaranya memberikan ulasan singkat bahwa applikasi sangat membantu dalam proses pemilihan mahasiswa berprestasi di UNAI, sementara 6,3\% yang menyatakan bahwa aplikasi masih perlu perbaikan. Kedepannya sistem ini perlu dilengkapi dengan analisis respon sistem pada saat penggunaan secara bersamaan oleh banyak pengguna.
\end{abstract}

Kata-kata kunci: Sistem Informasi, E-Voting, Pemilihanan Elektronik, Pemilihan langsung

\section{IMPLEMENTATION OF ANDROID E-VOTING SYSTEM IN DIRECT VOTING SYSTEM IN THE UNIVERSITAS ADVENT INDONESIA ENVIRONMENT USING LARAVEL FRAMEWORK}

\begin{abstract}
The objective to be achieved in this study is to provide a system that can be used by voters in choosing the desired candidate through Android-based smartphone media. The implementation of the e-voting system in the selection of outstanding students at Universitas Advent Indonesia (UNAI) showed that the interest in using the e-voting system was very high and it was very helpful in the selection process. More than $84 \%$ of voters who used the e-voting system in the selection of UNAI's outstanding students gave an excellent response and rating on the use of the application. From all of the users, 81 voters gave a brief review of the application and it usage, $68.4 \%$ of them gave a brief review that the application was very helpful in the selection process of outstanding students at UNAI, while $6.3 \%$ stated that the application still needed improvement. In the future this system needs to be equipped with an analysis of the system response when using it simultaneously by many users.
\end{abstract}

Key words: Information Systems, E-Voting, Electronic Voting, Direct Election

\section{Pendahuluan}

Seiring dengan berkembangnya ilmu pengetahuan dan teknologi, mempengaruhi kecenderungan manusia dalam melaksanakan berbagai aktifitas dalam kehidupan mereka. Kehadiran teknologi informasi dan komunikasi dapat memberikan manfaat serta dapat menjadi solusi dalam berbagai kegiatan yang dilakukan termasuk salah satunya dalam sistem pemilihan. Proses pemilihan yang umum dilakukan di Indoensia selama ini adalah pemilihan dengan cara konvensional 
dimana pemilih mendatangi tempat dimana proses pemilihan dilaksanakan lalu mengikuti proses pemilhan secara manual.

Dalam sistem pemilihan modern, internet bukan lagi hal baru dimana internet dapat memberikan banyak manfaat dalam mendukung proses pemilihan diantaranya akurasi, kemudahan, demokrasi, dapat diverifikasi, rahasia (Kohli et. al 2016), keamanan, keadilan, keunikan dan efisiensi (Sudhakar and Sai, 2015) serta juga mempermudah dalam proses pengumpulan dan penghitungan suara (Wagiu \& Palopak, 2017). Proses pemilihan sering terhambat dengan berbagai masalah salah satunya adalah proses pengumpulan dan penghitungan kembali suara yang membutuhkan waktu bahkan pada proses pemilihan yang berskala kecil sekalipun. Berbagai kendala yang dihadapi dalam sebuah proses pemilihan dapat diatasi salah satunya dengan penggunaan teknologi internet melalui e-voting dimana proses pemilihan terutama pemungutan suara dan penghitungan kembali dilakukan oleh sistem komputer (Ridwan, Arifin dan Yulianto, 2016).

Keberadaan teknologi internet memberikan manfaat yang cukup signifikan pada proses pemilihan dan pemungutan suara. Online Voting telah banyak dikembangkan dalam berbagai bentuk (Gibson et. al 2016), seperti halnya juga dibuat dalam proses pemilihan struktur pimpinan sebuah lembaga atau organisasi (Hendriyani, Dwiyani dan Putri, 2015). Demikian halnya di Universitas Advent Indonesia, banyak kegiatan yang melibatkan pemungutan suara seperti pemilihan ketua Badan Eksekutif Mahasiswa (BEM), pemilihan para ketua Himpunan Mahasiswa (HIMA) hingga kepada pemilihan mahsiswa-mahasiswa berprestasi yang melibatkan banyak kriteria serta melibatkan banyak pihak sebagai pemilih. Salah satu proses pemilihan yang rutin dilakukan di Universitas Advent Indonesia adalah pemilihan mahasiswa dan mahasiwi berprestasi yang dinilai dari berbagai kriteria yang disebut King dan Queen. Pemilihan King dan Queen diselenggarakan oleh panitia yang ditunjuk oleh Wakil Rektor Bidang Kemahasiswaan yang kemudian bekerja menentukan kriteria-kriteria calon hingga penentuan waktu pemilihan sebagai acara puncak untuk memilih seorang mahasiswa sebagai King dan seorang mahasiswi sebagai Queen. Acara puncak tersebut dihadiri oleh seluruh penghuni kampus yang juga sebagai pemilih.

Berhubung waktu yang ada untuk proses pemilihan di babak final ini hanya sedikit, sementara dibutuhkan partisipasi dari semua penghuni kampus untuk ikut memilih, maka diperlukan sebuah sistem yang dapat megumpulkan dan menghitung secara langsung (real time) hasil dari voting para pemilih. Dalam hal ini e-voting dapat merupakan pilihan yang efisien, aman dan mudah (Anamica dan Jayavel 2016, Velapure et.al, 2015) untuk memberikan suara, dimana aplikasi dapat dirancang dan dijalankan pada perangkat smartphone. Dengan teknologi dan jaringan mobile phone dapat memfasilitasi para pengguna untuk melakukan voting secara spontan dan tepat waktu (Steyn and Greunen, 2014). Penggunaan smartphone android dapat membantu proses pemungutan suara menjadi lebih mudah dan efisien (Meshram, et al., 2015). Untuk lebih memudahkan para pemilih dalam melakukan proses pemilihan maka Platform Android dapat digunakan untuk mengembangkan aplikasi voting online (Monisha et. al.,2015). Tujuan penelitian ini adalah merancang dan membangun sebuah sistem berbasis Android yang dapat digunakan untuk proses pemilihan mahasiswa dan mahasiswi berprestasi (King dan Queen) di Universitas Advent Indonesia dimana pemilihan dapat dilakukan oleh seluruh mahasiswa dan dosen serta melibatkan juri yang sudah ditentukan.

\section{Uraian Teori}

Menurut Mursi et al., (2013) bahwa pemilihan adalah sebuah proses untuk memperoleh data yang akurat dari sekumpulan orang yang berpartisipasi pada sebuah kegiatan dimana para partisipan tersebut memberikan jawaban terhadap suatu pertanyaan tertentu. Pada sebuah proses pemungutan suara umumnya terdiri dari serangkaian pilihan yang telah ditentukan yang disebut kandidat. Steyn dan Greunen (2014), mengatakan bahwa voting merupakan fitur penting dari setiap proses demokrasi dan merupakan ekspresi vital dari kekuatan rakyat.

Teknologi Informasi dan Komunikasi yang semakin berkembang memberikan peluang untuk dapat melakukan proses pemilihan walaupun menghadapi berbagai tantangan teknis (Gibson et. al., 2016). Menurut Monisha et. al. (2015) bahwa Komputasi bergerak dapat digunakan dalam mengatur voting online melalui smartphone. Kemajuan dalam perangkat mobile, teknologi nirkabel dan web 
yang diberikan untuk aplikasi baru yang akan membuat proses pemungutan suara sangat mudah dan efisien. Pemungutan suara online menjanjikan kemungkinan cara yang mudah dan aman untuk mengambil dan menghitung suara dalam pemilihan. Menurut Goyal et. al (2013), proses pemilihan dimungkinkan bagi pemilih untuk memberikan suara dengan cara yang sederhana dan nyaman tanpa batas waktu dan lokasi, dengan menggunakan SMS dan internet sehingga meningkatkan tingkat partisipasi voting, dan juga memastikan kerahasiaan dan anonimitas dengan menggunakan enkripsi dan dekripsi pada sistem dengan mengguna

Meshram et al (2015), bahwa berbagai kendala ditemui dalam sistem pemilihan tradisional, serta sistem pemilihan manual dengan menggunakan kertas suara memiliki banyak kekurangan (Steyn dan Greunen, 2014), sehingga sistem pemilihan mulai menggunakan bantuan komputer. Menurut Mursi et al., (2013) bahwa terdapat beberapa jenis sistem pemilihan dengan bantuan komputer seperti gambar 1. Anamica dan Jayavel (2016), bahwa Mobile Voting System (MVS) adalah cara yang sangat aman, efisien, dan mudah untuk memberikan suara. Sistem Mobile Voting menciptakan Sistem Voting Online dimana semua pengguna dapat menginput data dan server akan memperifikasi apakah mereka pengguna yang sah atau tidak. Jika valid, server akan memberikan ID dan Kata Sandi pengguna dengan menggunakan Application Program Interface (API) yang dapat menghasilkan dan mengirimkan One Time Password, nomor Enkripsi dan Dekripsi dan juga kriptografi visual.

Menurut More et. al. (2015), Sistem voting seluler adalah cara yang sangat aman, efisien, dan mudah untuk memberikan suara dengan menggunakan algoritma RSA untuk tujuan keamanan. Menurut Sidqi (2014), bahwa sistem pemungutan suara elektronik memiliki potensi untuk meningkatkan prosedur pemungutan suara tradisional dengan memberikan kenyamanan dan fleksibilitas tambahan kepada pemilih dengan menggunakan GSM (Global System for Mobile communications).

Penelitian terhadap implementasi penggunaan e-voting dilakukan oleh Steyn dan Greunen (2014) pada sebuah proses pemilihan di Afrika menunjukkan bahwa $93 \%$ dari peserta mengatakan apa yang mereka tidak suka kebanyakan tentang sistem pemungutan suara berbasis kertas saat ini adalah waktu antrian yang cukup lama. Sebanyak $73 \%$ peserta sangat setuju dan setuju bahwa aplikasi itu nyaman dan memuaskan untuk digunakan.

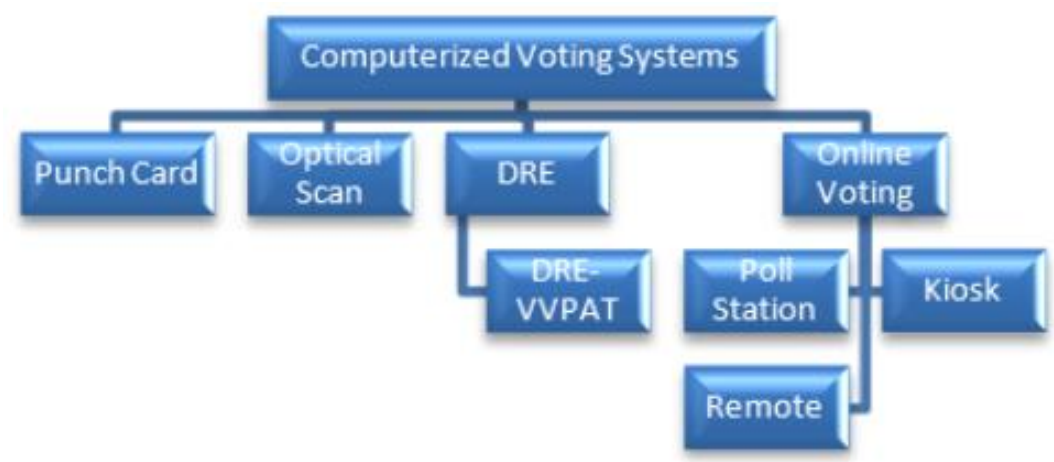

Gambar 1 Sistem Pemilihan berbasis komputer (Mursi et. al., 2013)

\section{Analisa dan Perancangan}

Proses pemilihan dimulai dari pembentukan panitia yang ditunjuk oleh Wakil Rektor Bidang Kemahasiswaan sebagai pengelola kegiatan kemahasiswaan. Selanjutnya tim yang sudah dibentuk akan melakukan penjaringan mahasiswa dan mahasiswi yang memenuhi syarat kriteria yang sudah ditentukan. Setelah melewati proses seleksi administrasi sebagai seleksi awal, masing-masing kandidat yang lolos seleksi awal akan tampil baik secara berpasangan maupun perorangan dihadapan para penonton/Voters yakni seluruh warga kampus UNAI serta dihadapan para Juri yang 
sudah ditentukan sebagai tim yang akan menguji kemampuan masing-masing calon. Para Juri dan penonton kemudian akan diberikan waktu untuk dapat melakukan vote terhadap kandidat yang mereka anggap layak sebagai pemenang melalui sistem e-voting yang sudah terlebih dahulu didownload dan diinstal pada perangkat android mereka untuk memilih kandidat mana yang mereka anggap cocok untuk menjadi King dan Queen.

Sistem voting berbasis Android digunakan oleh tiga jenis user yaitu Admin, Juri dan User/Voters. Terdapat beberapa fungsi aplikasi yang dapat dimanfaatkan oleh setiap pengguna seperti terlihat pada gambar 2 berikut.

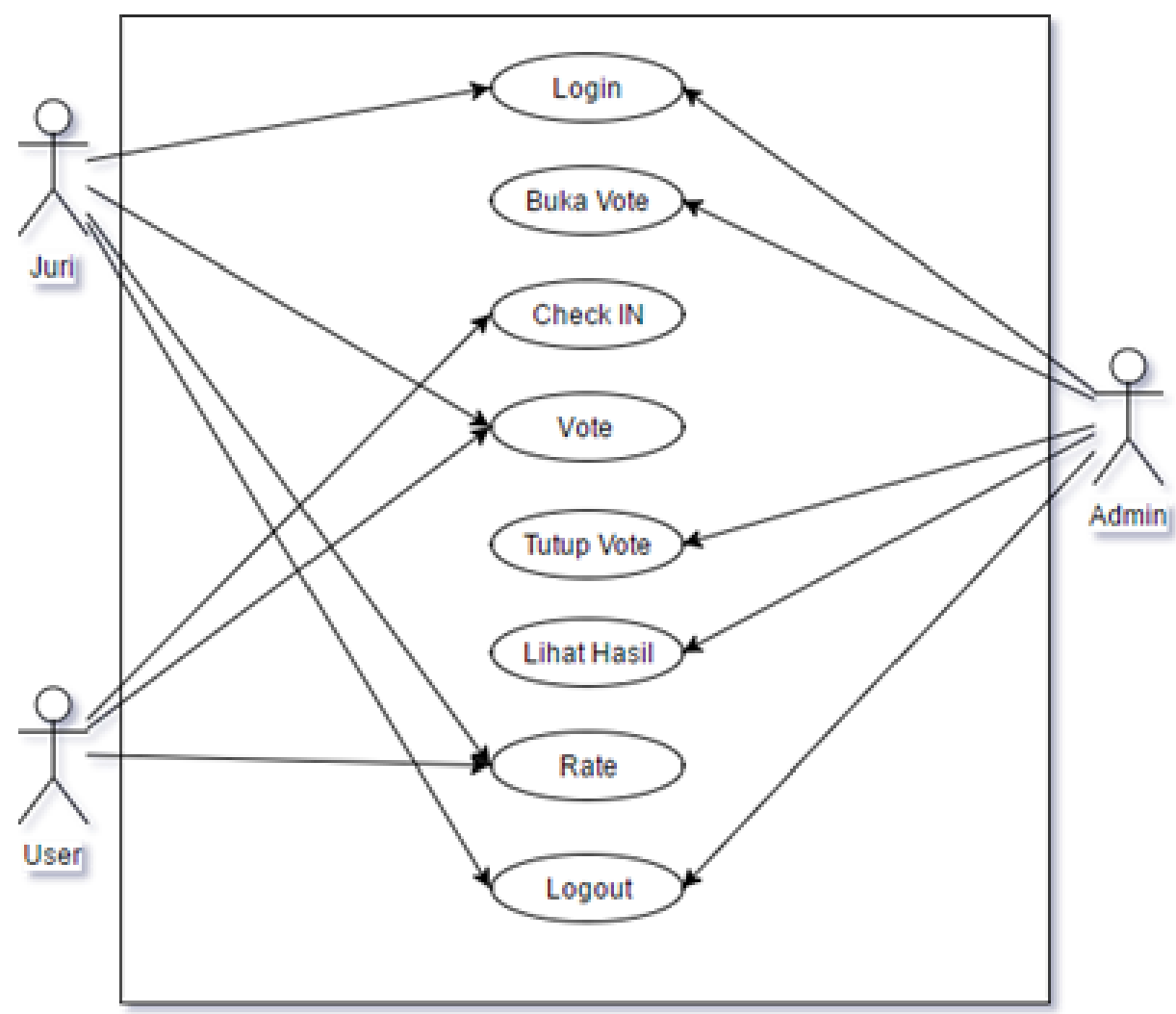

Gambar 2 Use Case Sistem

Admin berfungsi sebagai pengelola sistem, Juri sebagai penguji para kandidat dan merupakan bagian dari pemilih, User/Voters adalah seluruh penonton atau hadirin yang ikut memilih. Akan ada waktu terbatas bagi Juri dan seluruh Voters untuk melakukan proses pemilihan terhadap calon yang mereka akan pilih setelah proses tanya jawab oleh Juri. Admin akan membuka dan menutup waktu untuk voting. Selama waktu dibuka maka Juri beserta seluruh Voters dapat melakukan voting, sebaliknya jika waktu sudah ditutup maka Juri dan seluruh Voters tidak dapat melakukan voting. Untuk User/Voters terlebih dahulu harus melakukan check in pada aplikasi untuk memastikan bahwa mereka akan ikut dalam proses voting pada kandidiat yang sedang tampil. Setelah itu, waktu vote akan dibuka dan masing-masing User/Voters dapat memberikan suaranya untuk kandidat yang disukai seperti terlihat pada gambar 3 berikut. 


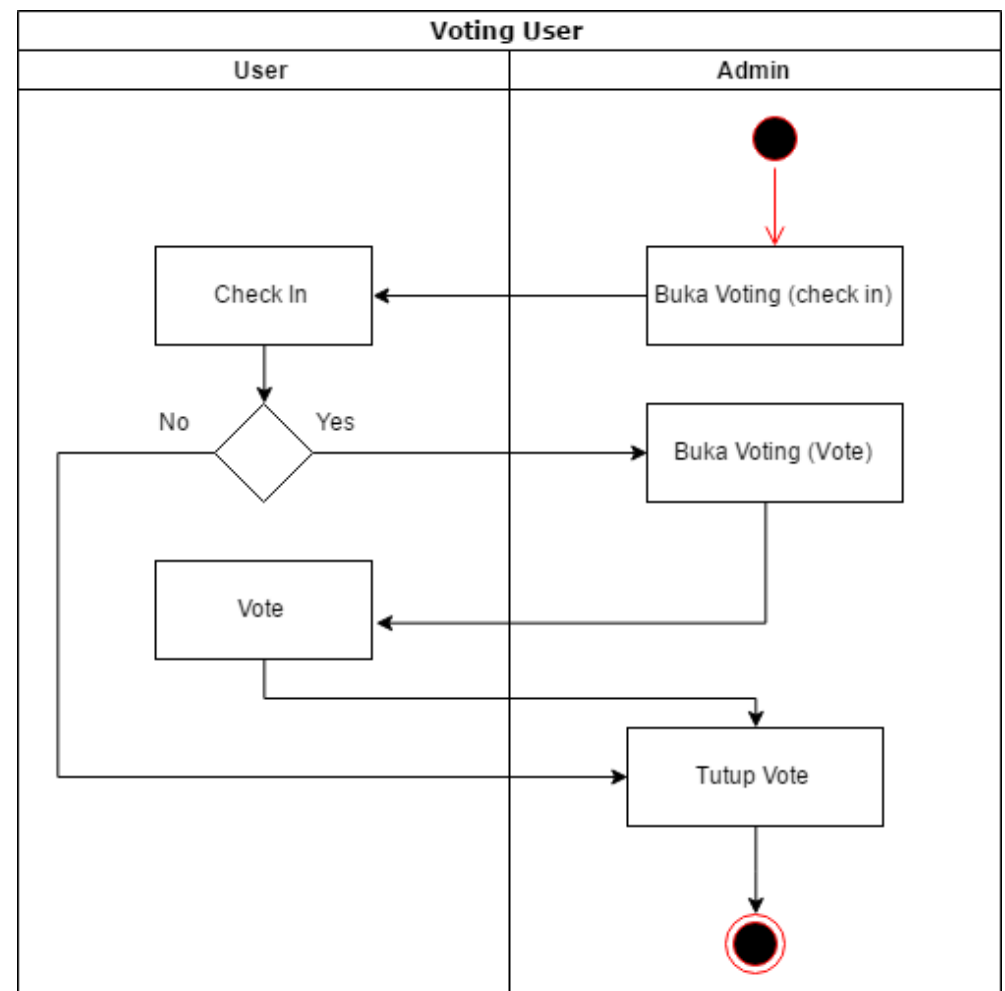

Gambar 3 Alur Voting User/Voters

Masing-masing Juri dan Voters dapat memilih kandidat dan mengirimkan hasilnya melalui aplikasi. Juri dapat melakukan voting secara langsung setelah waktu voting dibuka oleh Admin seperti terlihat pada gambar 4 berikut.

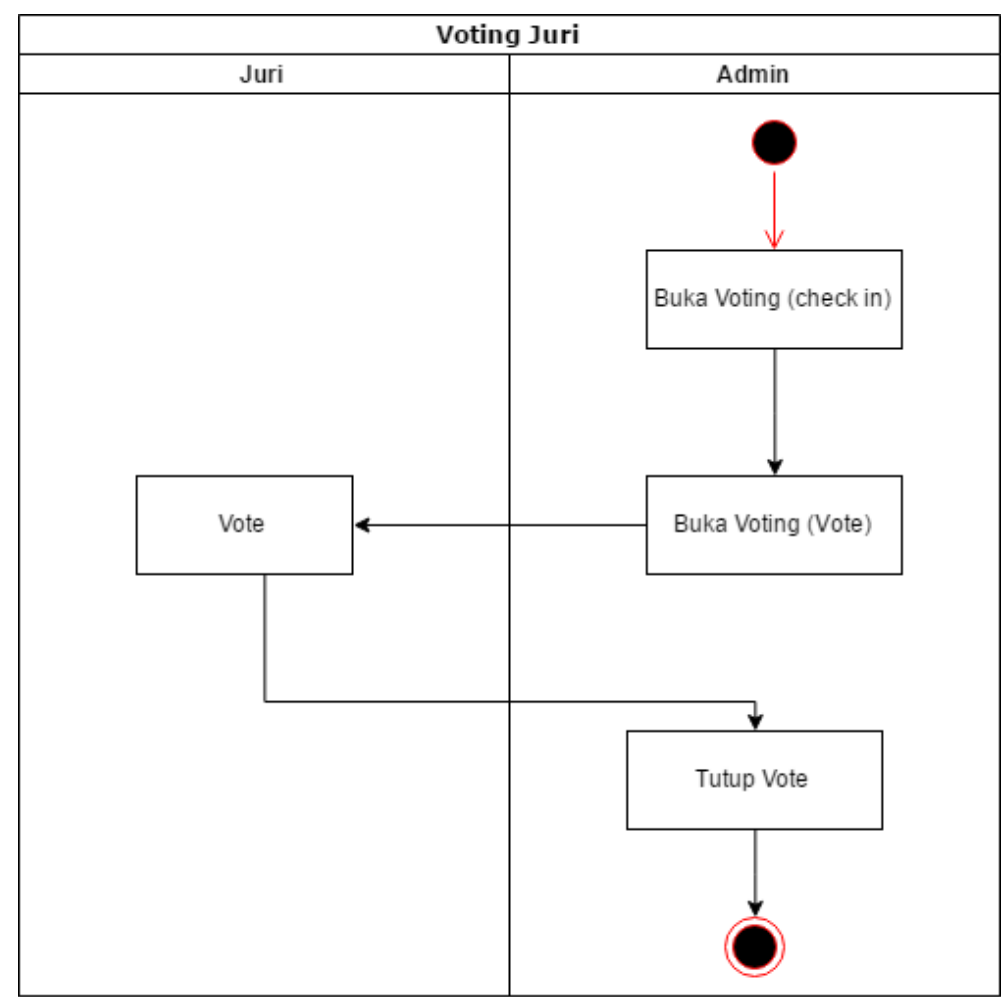

Gambar 4 Alur Voting Juri 
Selama proses voting berlangsung maka data jumlah perolehan suara para kandidat akan ditampilkan dalam bentuk persentase secara realtime sehingga hasil dari semua voter yang sudah terekam di sistem akan ditampilkan dan semua voters dapat melihat persentasi perolehan suara masing-masing kandidat. Dari data voting yang masuk maka dapat disimpulkan siapa pemenang dari pemilihan tersebut. Sistem voting berbasis Android ini dirancang untuk dapat digunakan secara langsung oleh semua user yang mendownload dan menginstal aplikasinya pada perangkat smartphone masing-masing.

\section{Hasil dan Pembahasan}

Aplikasi e-voting berbasis android merupakan aplikasi yang digunakan untuk memilih mahasiswa/i berprestasi di UNAI. Implementasi dari aplikasi e-voting ini dilakukan pada kegiatan pemilihan mahasiswa/i berprestasi di lingkungan Universitas Advent Indonesia yang dilaksanakan pada tanggal 16 April 2017. Pengguna aplikasi adalah seluruh penghuni kampus yang mengikuti acara pemilihan tersebut secara langsung. Aplikasi dapat diunduh oleh setiap warga kampus yang menggunakan perangkat handphone android dari Google Playstore. Masing-masing pemilih dapat mengunduh aplikasi dan mengistal aplikasi tersebut pada perangkat android mereka. Aplikasi tersebut hanya dapat digunakan pada waktu yang sudah ditentukan dimana proses pemilihan dilaksanakan.

Terdapat dua menu yang dapat dipilih oleh para pengguna seperti pada gambar 5. Menu Live Voting digunakan untuk memilih kandidat yang diinginkan, sedangkan menu Rate digunakan untuk memberikan rating atau umpan balik atas penggunaan aplikasi tersebut. Untuk melakukan proses voting, User/Voters dapat memilh menu Live Voting dan selanjutnya ditampilkan para kandidat mahsiswa yang akan dipilih.

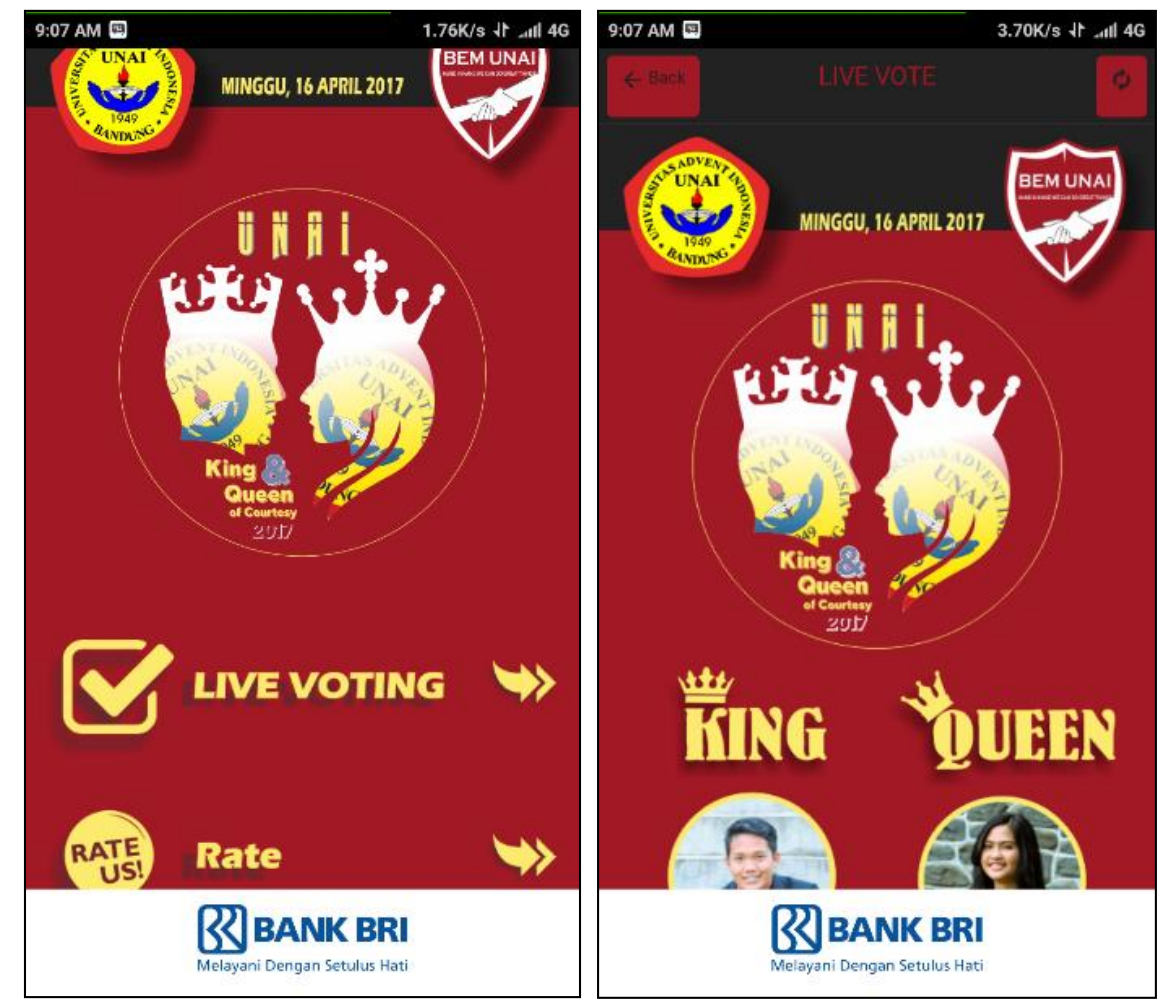

Gambar 5 Tampilan Menu

Proses pemilihan ini diikuti oleh 12 orang kandidat yang teridiri dari 6 orang pria dan 6 orang wanita. Dari kedua belas orang tersebut akan dipilih satu orang pria dan satu orang wanita sebagai mahasiswa/i terbaik UNAI. Proses voting menggunakan aplikasi e-voting dibuka untuk seluruh 
pemilih sesaat sebelum para kandidat tampil ke podium untuk menampilkan keterampilan mereka serta untuk diuji oleh para juri. Proses dimulai dari proses Check In untuk memberikan kesempatan kepada seluruh pemilih untuk ikut memilih kandidat yang sedang tampil. Waktu untuk Check In akan dibuka oleh Admin, dan akan diberikan beberapa menit bagi seluruh voters untuk melakukan Check In. Jika pemilih melakukan Check In, berarti pemilih tersebut akan ikut memilih kandidat yang bersangkutan, sebaliknya jika tidak melalukan Check In, maka voters tidak dapat memberikan suaranya untuk kandidat yang bersangkutan. Aplikasi akan menampilkan gambar kandidat yang akan di pilih jika sudah melakukan Check In. Selanjutnya aplikasi akan mengarahkan untuk menunggu waktu voting dibuka seperti tampilan pada gambar 6 berikut.

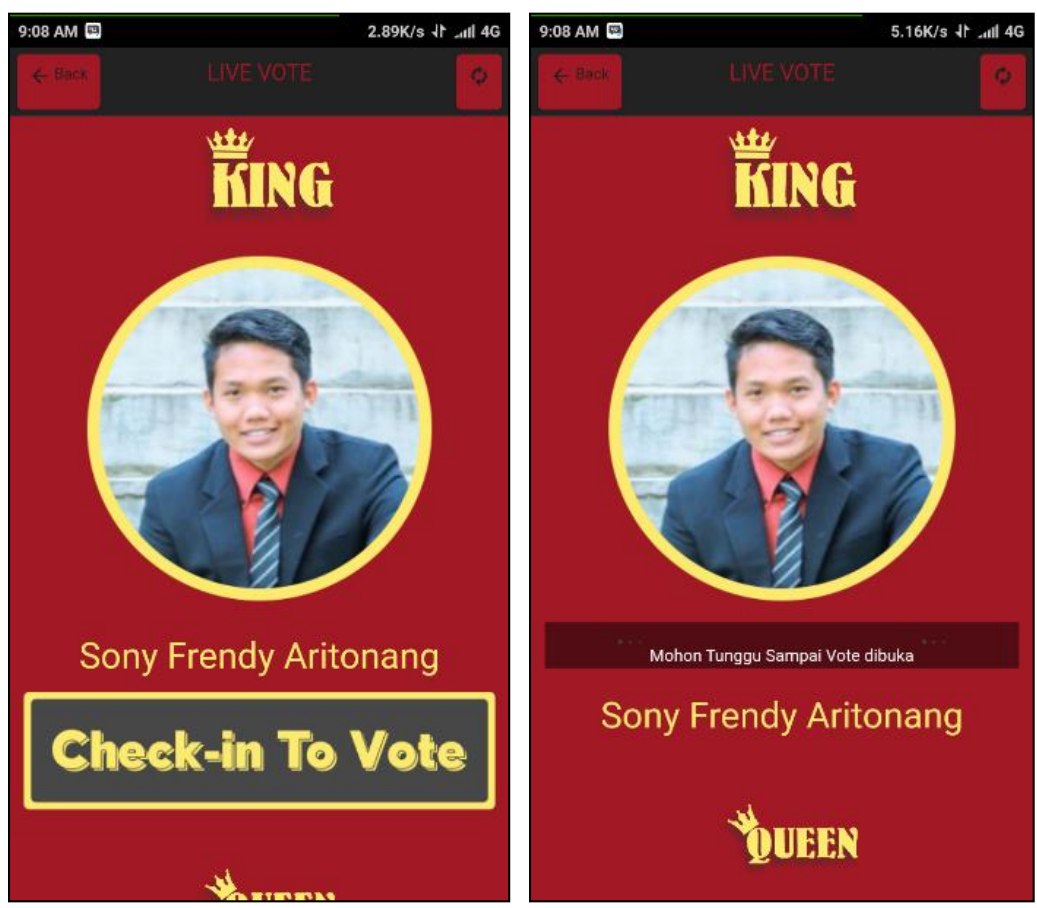

Gambar 6 Tampilan menu Check In

Setelah waktu Check In berakhir dan waktu untuk voting di buka maka aplikasi akan menampilkan gambar kandidat serta tombol untuk melakukan voting secara online seperti tampilan pada gambar 7. Para pemilih dapat menekan tombol untuk memilih atau juga tombol untuk tidak memilih. 


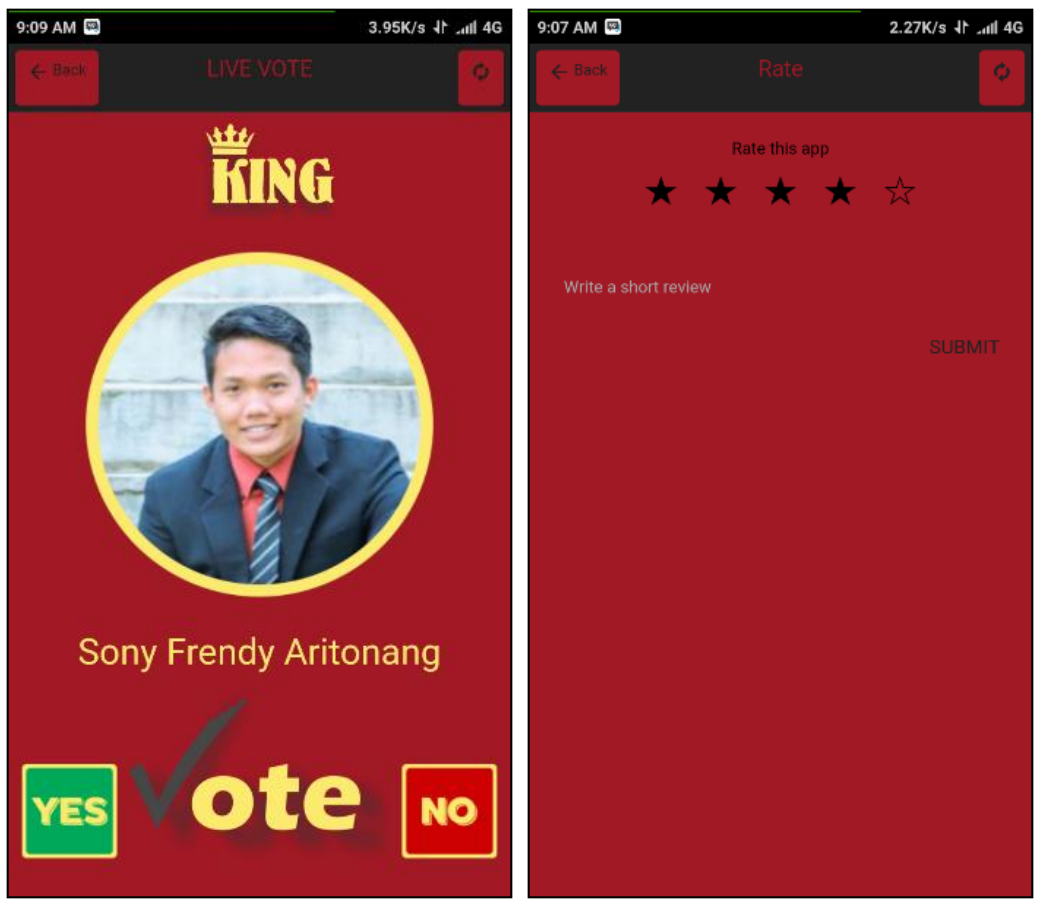

Gambar 7 Tampilan Vote

Hasil dari seluruh Voters yang akan disimpan di server dan akan ditampilkan secara real time oleh aplikasi sehingga setiap pengguna aplikasi dapat melihat perolehan suara masing-masing kandidat seperti terlihat pada gambar 8 yang ditampilkan dalam bentuk grafik.

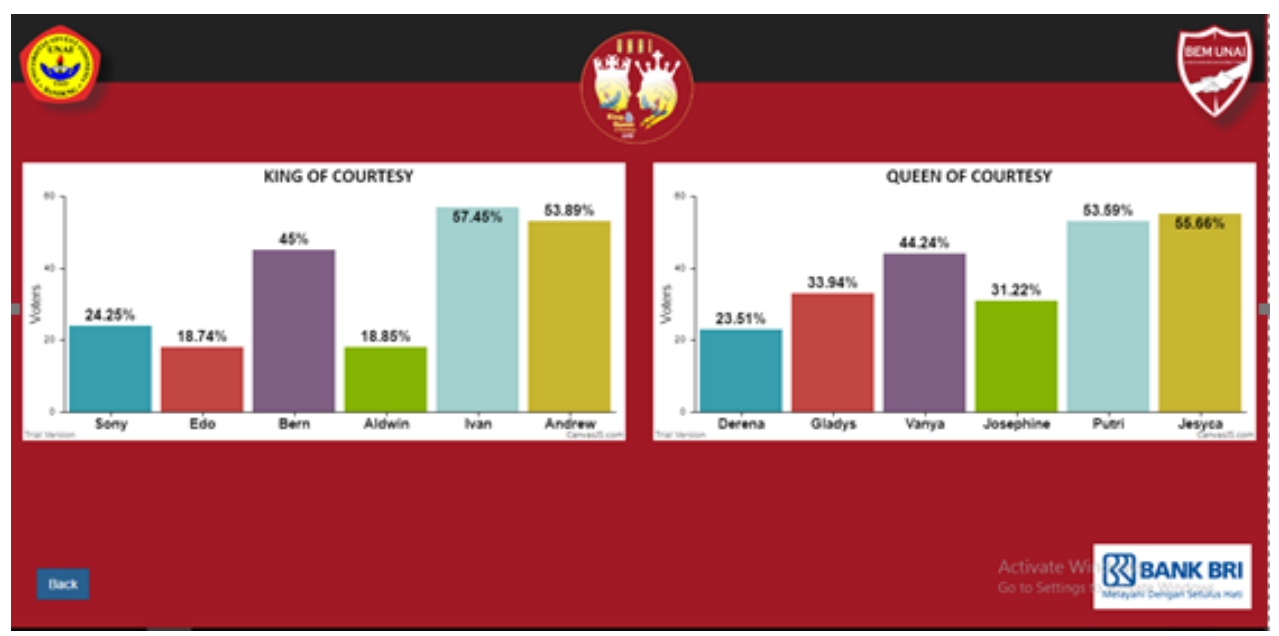

Gambar 8 Tampilan Hasil Voting

Pada akahir proses voting, para pemilih diminta untuk memberikan rating dan ulasan terhadap aplikasi dengan memberikan rating bintang antara 1 sampai dengan 5, dengan asumsi bahwa rating 4 dan 5 mewakili bahwa pengguna aplikasi tersebut senang dan terbantu dalam penggunaan aplikasi e-voting ini. Jumlah pemilih yang memberikan respon adalah 274 orang seperti terlihat pada table 1. Rata-rata rating dari seluruh jumlah pemilih tersebut adalah 4,67. Hal ini menunjukkan bahwa secara rata, rating yang diberikan oleh pemilih mendekati angka 5 yang dapat diartikan bahwa penggunaan palikasi memang membantu para pemilih. Dari hasil umpan balik yang diterima terlihat bahwa $84,3 \%$ pengguna aplikasi memberikan rating 5 yang dapat disimpulkan bahwa mereka senang dan terbantu dalam menggunakan aplikasi e-voting tersebut. 
Tabel 1 Hasil umpan balik pemilih

\begin{tabular}{ccc}
\hline Rating & Jumlah & Persentase \\
\hline 1 & 11 & 0,040 \\
2 & 4 & 0,015 \\
3 & 7 & 0,026 \\
4 & 21 & 0,077 \\
5 & 231 & 0,843 \\
\hline
\end{tabular}

Disamping memberikan rating, para pemilih juga diberikan kesempatan untuk menuliskan ulasan setelah memberikan rating pada kolom review aplikasi. Sebanyak 81 pemilih memberikan ulasan singkat yang dapat dikelompokkan menjadi tiga kelompok untama seperti terlihat pada tabel 2.1. Sebanyak 54 atau $68,4 \%$ dari pemilih yang memberikan ulasan menyatakan bahwa aplikasi ini bagus dan sangat membantu. Terdapat 5 orang atau 6,3\% pengguna menyatakan bahwa applikasi masih perlu perbaikan selanjutnya, dan sisanya sebanyak $25,3 \%$ memberikan ulasan yang tidak berhubungan langsung dengan penggunaan aplikasi.

Tabel 2 Komentar pengguna aplikasi

\begin{tabular}{lcc}
\hline \multicolumn{1}{c}{ Ulasan } & Jumlah & Persentase \\
\hline Aplikasi membantu & 54 & 0,684 \\
Aplikasi Perlu perbaikan & 5 & 0,063 \\
Tidak berhubungan dengan applikasi & 20 & 0,253 \\
\hline
\end{tabular}

\section{Kesimpulan dan Saran}

Hasil dari penelitian ini adalah perancangan dan implementasi sebuah aplikasi yang digunakan untuk membantu melaksanakan proses pemilihan mahasiswa berprestasi di lingkungan Universitas Advent Indonesia. Didapati bahwa proses pemilihan berlangsung dengan baik dengan dukungan teknologi dan aplikasi berbasis android. Sebanyak 274 orang menggunakan aplikasi pada proses pemilihan tersebut dan $84 \%$ dari pengguna tersebut memberikan respon dan rating yang sangat baik terhadap penggunaan aplikasi. Dari sejumlah pengguna, sebanyak 81 pemilih yang memberikan ulasan singkat mengenai aplikasi dan penggunaannya. Sebanyak $68,4 \%$ yang memberikan ulasan singkat bahwa applikasi sangat membantu dalam proses pemilihan mahasiswa berprestasi di UNAI, sementara 6,3\% yang menyatakan bahwa aplikasi masih perlu perbaikan.

Pada implementasi aplikasi e-voting ini masih mengalami beberapa kendala yang cukup berarti yakni dukungan server yang kurang memadai sehingga membuat aplikasi menjadi sangat lambat dengan pengguna yang banyak. Kedepannya diharapkan pengembangan yang lebih lanjut dengan menambahkan fitur-fitur lain yang dibutuhkan serta penggunaan server yang memadai.

\section{Referensi}

1. B. Monisha, S. Abiramani, S. Gayathri Priyadharshini, Prasanth Yokesh. Online Voting Through Smartphones Implementation Using Mobile Computing. International Journal of Innovative Research in Computer and Communication Engineering, ISO 3297: 2007 Certified Organization Vol.3, Special Issue 8, October 2015. ISSN(Online): 2320-9801. ISSN (Print): 2320-9798

2. C. Wagiu dan Y. Palopak. Rancang Bangun Sistem E-Voting berbasis Web. Jurnal Teknologi Informasi dan Komunikasi, Vol. 7 No.1, April 2017 Issn:1979-6439.

3. Dipali More, Mehzabin Shaikh, Meera Awaskar, Supriya Ghongde, Sampada Wattamwar, Divya Tadpelliwar. Mobile Voting System. International Journal of Emerging Technology and Advanced 
Engineering ISSN: 2250-2459, ISO 9001:2008 Certified Journal, Volume 5, Issue 1, January 2015.

4. Dinesh Goyal, Dr. Naveen Hemrajani, Gajanand Sharma, Ravi Sr Sharma, Dr. Ruchi Goyal. Secure Voting System in a Mobile Network. International Journal of Computer and Information Technology (ISSN: 2279 - 0764) Volume 02- Issue 02, March 2013

5. Haval Mohammed Sidqi. E-Voting System Using GSM Mobile SMS. International Journal of Emerging Trends \& Technology in Computer Science (IJETTCS), Volume 3, Issue 4, July-August 2014. ISSN 2278-6856

6. J. Paul Gibson, Robert Krimmer, Vanessa Teague and Julia Pomares. A review of E-voting: the past, present and future. Institut Mines-T'el'ecom and Springer-Verlag France 2016. DOI 10.1007/s12243-016-0525-8

7. Mona F.M. Mursi, Ghazy M.R. Asassa, Ahmed Abdelhafez and Kareem M. Abo Smara. On the Development of Electronic Voting: A Survey. International Journal of Computer Applications (0975 - 8887) Volume 61- No.16, January 2013

8. Mona F.M. Mursi, Ghazy M.R. Assassa, Ahmed Abdelhafez and Kareem M. Abo Samra. On the Development of Electronic Voting: A Survey. International Journal of Computer Applications (0975 - 8887) Volume 61- No.16, January 2013

9. Muhammad Ridwan1, Zainal Arifin dan Yulianto. Rancang Bangun E-Voting Dengan Menggunakan Keamanan Algoritma Rivest Shamir Adleman (Rsa) Berbasis Web (Studi Kasus: Pemilihan Ketua Bem Fmipa). Jurnal Informatika Mulawarman Vol. 11, No. 2, September 2016 ISSN 1858-4853

10. M.Sudhakar and B. Divya Soundarya Sai. Biometric System Based Electronic Voting Machine Using Arm9 Microcontroller. IOSR Journal of Electronics and Communication Engineering (IOSRJECE) ISSN: 2278-8735.Volume 10, Issue 1, Ver. II (Jan - Feb. 2015), PP 57-65

11. Nitan Kohli, Himanshu Saurav, Devesh Samrat and Pratyush. A Real Time E-Voting System: An Initiative towards Digital India. International Journal of Engineering Trends and Technology (IJETT) - Volume 35 Number 3- May 2016.ISSN: 2231-5381

12. Prof. D. A. Meshram, Magdum Komal A., Pisal Pooja P., Gund Shrikant V., Wagh Ruchira S. Online Voting System Using Android Application. International Journal of Advance Research in Computer Science and Management Studies, Volume 3, Issue 2, February 2015 pg. 314-316. SSN: 2327782 (Online)

13. P. Manivannan and K. Ramesh. E-Voting System Using Android Smartphone. International Research Journal of Engineering and Technology (IRJET) Volume: 02 Issue: 06, Sep-2015. ISSN: 2395-0072, e-ISSN: 2395-0056

14. Prashant Pandit, Sagar Bhawar and Prof. Manisha Desai. Campus E-Voting for Android and Web Based Application. International Journal of Emerging Engineering Research and Technology, Volume 2, Issue 7, October 2014, PP 95-100. ISSN 2349-4395 (Print) \& ISSN 2349-4409 (Online)

15. Steyn, J., Van Greunen, D. (Eds). (2014). Designing, developing and testing a mobile phone voting system in the South African context. ICTs for inclusive communities in developing societies. Proceedings of the 8th International Development Informatics Association Conference, held in Port Elizabeth, South Africa. ISBN: 978-0-620-63498-4 Pages 372-385

16. Yeka Hendriyani, Nurindah Dwiyani dan Vivin Mahat Putri. Perancangan Aplikasi E-Election Berbasis Sms Gateway. Jurnal Teknologi Informasi \& Pendidikan Issn: 2086 - 4981 Vol. 8 No. 1 Maret 201515 